\title{
Growth and yield of Vigna radiata L.) under Terminalia arjuna and Mitragyna parvifolia based agrisilvicultural system
}

\author{
S. Kumar*, L. K. Behera, N. S. Patil and D. B. Jadeja \\ College of Forestry, Navsari Agricultural University, Navsari- 396450 (Gujarat), INDIA \\ *Corresponding author. E-mail: shrawan.forestry@gmail.com
}

Received: March 3 2015; Revised received: August 11, 2015; Accepted: September 24, 2015

\begin{abstract}
The present investigation was carried out in an agrisilvicultural system with treatments involving silvicultural component of 20 years old Terminalia arjuna Bedd. (Arjun) and Mitragyna parvifolia Korth (Kalam) intercropped with agricultural component of four varieties of green gram (Vigna radiata L.) viz. Pusa Vishal, GM-3, GM-4 and K-851. All the varieties of green gram were compared for growth and yield parameters like plant height $(\mathrm{cm})$, number of leaves, number of branches per plant, total grain yield per plant as well as per plot at harvestable stage under Arjuna and Kalam trees. All the varieties of green gram performed superior in terms of number of leaves, numbers of branches, grain yield (per plant and per plot basis) under open condition as compared to crops under Arjuna and Kalam. However, only the plant height was found to be highest under Arjun, followed by Kalam trees. Among all the varieties tested, K-851 variety showed superiority for number of leaves (12.31) and number of branches per plant (3.96) and grain yield (2.66 gm per plant and $0.80 \mathrm{~kg}$ per plot) as compared to other varieties (at $\mathrm{P}=0.05$ ). Therefore, this variety is suggested to grow in south Gujarat condition. Further, comparatively lower yield of crop under tree cover could be due to shade effect, which can be managed by regular pruning of tree branches.
\end{abstract}

Keywords: Agrisilvicultural system, Arjun, Green gram, Growth, Kalam, Yield

\section{INTRODUCTION}

Agroforestry is a farming system integrating crop and/ or livestock with trees and shrubs in order to obtain economic, environmental, ecological and cultural benefits (Thevathasan et al., 2004). Particularly, interactions among different components of agroforestry provides multiple benefits i.e. diversified farm income, increased biological production, better water quality and improved habitat for both humans and wildlife. An efficient agroforestry system would aim at systematically developing integrated land use systems and practices where the positive interaction between trees and crops are encouraged and maximized. It offers an economical and ecologically viable option for large scale diversification in agriculture on one hand and environmental amelioration on the other (Nayak et al., 2014). Agroforestry systems are designed for beneficial interactions of the crop plants and to reduce unfavourable interactions. These are designed to reduce the risks associated with agriculture, small scale or large and to increase the sustainability of agriculture. On-farm timber tree plantations can also benefit from the global environmental facilities like carbon trading (Pandey, 2007; Dogra, 2007). Therefore, there is a great need to identify the suitable agricultural and horticultural crops, which can grow well along with tree species with limited solar energy available underneath the trees (Nayak et al., 2014). Terminalia arjuna
Bedd. (Arjun) belongs to family combretaceae is an important multipurpose tree. It is common throughout the greater part of Indian peninsula along rivers, streams, ravines and dry water courses. The heart wood is brown and sapwood is pinkish white in colour. The wood is very hard and can be used for building, agricultural implements, carts, boats, pit props, watertroughs and other domestic purposes. The bark is used for tanning and is much collected for the purpose in central India (CBD, 2012). Mitragyna parvifolia Korth. (Kalam) belongs to family rubiaceae and found throughout the greater part of India. The wood is light pinkish brown, evenly grained and a shade lighter than teak but of the same hardness. The wood is generally used for agricultural implements, building and other domestic uses (CBD, 2012). Vigna radiata L. (Green gram) belongs to fabaceae family. In India, it is cultivated in almost all the states. The important green gram growing states are Orissa, Maharashtra, Andhra Pradesh, Madhya Pradesh, Gujarat, Rajasthan and Bihar. It is consumed as whole grain as well as split pulse (Dal). Green gram (moong) is an excellent source of high quantity protein which is about 25 per cent. It is also used as green manuaring crop. Being a leguminous crop, it has capacity to fix the atmospheric nitrogen and also helps in preventing soil erosion. Being a short duration crop it fits well in many intensive crop rotations. After harvesting the pods, green plants are uprooted or cut from ground level and 
chopped in to small pieces and fed to the cattle. Intercropping of pulses between rows of timber tree species may provide good opportunity to diversify agroforestry and increase economic returns to the farming community due to fast growth and valuable timber (Chauhan et al., 2013). The choice of intercrop also depends on characteristics of particular tree species like root system, canopy, allelopathic effect of litter and technical factors viz. agro-climatic and edaphic conditions (Batish et al., 2007). Besides the cereals, vegetables, flowers and pulse crops are also grown as an intercrops with trees; however, pulse crops are found to be more remunerative due to short duration and easy cultivation. Looking to above, an attempt was made with the objective to evaluate the growth and yield of varieties of green gram as an intercrop under forest tree species in an established Arjun and Kalam based agrisilvicultural system in south Gujarat condition.

\section{MATERIALS AND METHODS}

Present investigation was started at the instructional farm, College of Forestry, Navsari Agricultural University under the established tree species of Arjun and Kalam of 20 years old planted at a spacing of $10 \mathrm{~m}$ $\times 2.5 \mathrm{~m}$. Four green gram varieties Pusa Vishal, GM-3, GM-4 and K-851were selected on the basis of their production and demand in the Gujarat and sowing at a spacing of $30 \mathrm{~cm} \times 10 \mathrm{~cm}$ in a net plot size of $1.60 \mathrm{~m} \times$ $5.70 \mathrm{~m}$ respectively. The trial was conducted in a randomised block design with factorial concept (FRBD) having three replications with fixing treatments as T0 (Control), T1 (Arjun), T2 (Kalam) and V1 (Pusa Vishal), V2 (GM-3), V3 (GM-4), V4 (K-851). The experimental field was prepared by ploughing followed by discing twice and seeds of green gram were sowing during 2nd week of March, after that immediately irrigation was applied. All the plant protection measures along with irrigation were carried out as per requirement. The harvesting of green gram was done when most of pods were mature as over maturity may result in shattering. Five plants were randomly selected from each net plot of each treatment and tagged for recording the observations. Growth parameters like plant height $(\mathrm{cm})$, number of leaves per plant and number of branches per plant and yield parameters like grain yield per plant (gm) and grain yield per plot (kg) were observed. The data of all the parameters studied were subjected to the statistical analysis for proper interpretation. A standard method of "Analysis of Variance' was used for analyzing the data suggested by Panse and Sukhatme (1978).

\section{RESULTS AND DISCUSSION}

Out of different growth parameters, plant height of green gram was significantly influenced by the tree species under agrisilvicultural system. The maximum plant height $(31.17 \mathrm{~cm})$ of crop was recorded under Arjun as compared to minimum $(26.96 \mathrm{~cm})$ plant height recorded in Control (Table 1). The reason for more height under Arjun may be due to partial shade as compared to Kalam. This might be due to reduction in the rate of evaporation of water from soil under Arjun and also due to photosynthesis rate which may be proportional to chlorophyll content only at low light intensity. An increase in chlorophyll does not increase photosynthesis rate as light becomes a limiting factor, though chlorophyll content increase under tree species but the photosynthetic activity was limited by low light

Table 1. Plant height $(\mathrm{cm})$ of green gram $(V$. radiata $)$ as influenced by forest tree species at harvesting stage.

\begin{tabular}{|c|c|c|c|c|c|}
\hline \multirow{2}{*}{ Treatments } & \multicolumn{4}{|c|}{ Green gram $(V$. radiata $)$ varieties } & \multirow{2}{*}{ Mean } \\
\hline & Pusa Vishal $\left(V_{1}\right)$ & GM-3 $\left(V_{2}\right)$ & GM-4 $\left(V_{3}\right)$ & $\mathbf{K}-851\left(\mathrm{~V}_{4}\right)$ & \\
\hline $\mathrm{T}_{0}$ (Control) & 24.38 & 30.13 & 25.73 & 27.60 & 26.96 \\
\hline $\mathrm{T}_{1}$ (Arjun) & 32.25 & 31.32 & 30.30 & 30.18 & 31.17 \\
\hline $\mathrm{T}_{2}$ (Kalam) & 28.10 & 27.90 & 26.75 & 27.93 & 27.67 \\
\hline Mean & 28.24 & 29.78 & 27.59 & 28.78 & \\
\hline Source & \multicolumn{2}{|c|}{ S. Em. \pm} & \multicolumn{2}{|c|}{ C.D. at $5 \%$} & C.V. $\%$ \\
\hline $\mathrm{T}$ & \multicolumn{2}{|c|}{0.834} & \multicolumn{2}{|c|}{2.44} & \\
\hline V & \multicolumn{2}{|c|}{0.963} & \multicolumn{2}{|c|}{ NS } & 10.10 \\
\hline $\mathrm{T} \times \mathrm{V}$ & \multicolumn{2}{|c|}{1.668} & \multicolumn{2}{|c|}{ NS } & \\
\hline
\end{tabular}

Table 2. Number of leaves per plant of green gram $(V$. radiata $)$ as influenced by forest tree species at harvesting stage.

\begin{tabular}{|c|c|c|c|c|c|}
\hline \multirow{2}{*}{ Treatments } & \multicolumn{4}{|c|}{ Green gram $(V$. radiata $)$ varieties } & \multirow{2}{*}{ Mean } \\
\hline & Pusa Vishal $\left(V_{1}\right)$ & GM-3 $\left(V_{2}\right)$ & GM-4 $\left(V_{3}\right)$ & $\mathrm{K}-851\left(\mathrm{~V}_{4}\right)$ & \\
\hline $\mathrm{T}_{0}($ Control $)$ & 12.80 & 12.46 & 11.80 & 13.06 & 12.53 \\
\hline $\mathrm{T}_{1}$ (Arjun) & 10.93 & 12.20 & 12.33 & 12.73 & 12.05 \\
\hline $\mathrm{T}_{2}($ Kalam $)$ & 11.23 & 11.40 & 11.06 & 11.13 & 11.20 \\
\hline Mean & 11.65 & 12.02 & 11.73 & 12.31 & \\
\hline Source & \multicolumn{2}{|c|}{ S. Em. +} & \multicolumn{2}{|c|}{ C.D. at $5 \%$} & C.V. \% \\
\hline $\mathrm{T}$ & \multicolumn{2}{|c|}{$0.297^{-}$} & \multicolumn{2}{|c|}{0.873} & \\
\hline $\mathrm{V}$ & \multicolumn{2}{|c|}{0.343} & \multicolumn{2}{|c|}{ NS } & 8.67 \\
\hline $\mathrm{T} \times \mathrm{V}$ & \multicolumn{2}{|c|}{0.595} & \multicolumn{2}{|c|}{ NS } & \\
\hline
\end{tabular}


Table 3. Number of branches per plant in green gram ( $V$. radiata $)$ as influenced by forest tree species at harvesting stage.

\begin{tabular}{|c|c|c|c|c|c|}
\hline \multirow{2}{*}{ Treatments } & \multicolumn{4}{|c|}{ Green gram $(V$. radiata) varieties } & \multirow{2}{*}{ Mean } \\
\hline & Pusa Vishal $\left(V_{1}\right)$ & GM-3 $\left(V_{2}\right)$ & GM-4 $\left(V_{3}\right)$ & $\mathrm{K}-851\left(\mathrm{~V}_{4}\right)$ & \\
\hline $\mathrm{T}_{0}$ (Control) & 5.17 & 4.60 & 4.55 & 4.88 & 4.80 \\
\hline $\mathrm{T}_{1}$ (Arjun) & 2.70 & 2.93 & 2.67 & 3.35 & 2.96 \\
\hline $\mathrm{T}_{2}$ (Kalam) & 2.96 & 3.14 & 2.88 & 3.65 & 3.16 \\
\hline Mean & 3.61 & 3.56 & 3.37 & 3.96 & \\
\hline Source & \multicolumn{2}{|c|}{ S. Em. \pm} & \multicolumn{2}{|c|}{ C.D. at $5 \%$} & C.V. \% \\
\hline $\mathrm{T}$ & \multicolumn{2}{|c|}{$0.096^{-}$} & \multicolumn{2}{|c|}{0.28} & \\
\hline V & \multicolumn{2}{|c|}{0.111} & \multicolumn{2}{|c|}{0.33} & 9.18 \\
\hline $\mathrm{T} \times \mathrm{V}$ & \multicolumn{2}{|c|}{0.192} & \multicolumn{2}{|c|}{ NS } & \\
\hline
\end{tabular}

Table 4. Grain yield per plant (gm) of Green gram ( $V$. radiata) as influenced by forest tree species at harvesting.

\begin{tabular}{|c|c|c|c|c|c|}
\hline \multirow{2}{*}{ Treatments } & \multicolumn{4}{|c|}{ Green gram (V. radiata) varieties } & \multirow{2}{*}{ Mean } \\
\hline & Pusa Vishal $\left(V_{1}\right)$ & GM-3 $\left(V_{2}\right)$ & GM-4 $\left(V_{3}\right)$ & $\mathrm{K}-851\left(\mathrm{~V}_{4}\right)$ & \\
\hline $\mathrm{T}_{0}$ (Control) & 3.64 & 2.65 & 2.56 & 3.56 & 3.10 \\
\hline $\mathrm{T}_{1}$ (Arjun) & 1.30 & 1.42 & 1.32 & 1.45 & 1.37 \\
\hline $\mathrm{T}_{2}$ (Kalam) & 1.92 & 2.15 & 1.85 & 2.96 & 2.22 \\
\hline Mean & 2.29 & 2.07 & 1.91 & 2.66 & \\
\hline Source & \multicolumn{2}{|c|}{ S. Em. \pm} & \multicolumn{2}{|c|}{ C.D. at $5 \%$} & C.V. \% \\
\hline $\mathrm{T}$ & \multicolumn{2}{|c|}{$0.078^{-}$} & \multicolumn{2}{|c|}{0.23} & \\
\hline $\mathrm{V}$ & \multicolumn{2}{|c|}{0.090} & \multicolumn{2}{|c|}{0.27} & 12.15 \\
\hline $\mathrm{T} \times \mathrm{V}$ & \multicolumn{2}{|c|}{0.157} & \multicolumn{2}{|c|}{0.46} & \\
\hline
\end{tabular}

Table 5. Yield (kg) per plot of green gram ( $V$. radiata) as influenced by forest tree species at harvesting stage.

\begin{tabular}{|c|c|c|c|c|c|}
\hline \multirow{2}{*}{ Treatments } & \multicolumn{4}{|c|}{ Green gram (V. radiata) varieties } & \multirow{2}{*}{ Mean } \\
\hline & Pusa Vishal $\left(V_{1}\right)$ & GM-3 $\left(V_{2}\right)$ & GM-4 $\left(V_{3}\right)$ & $\mathrm{K}-851\left(\mathrm{~V}_{4}\right)$ & \\
\hline $\mathrm{T}_{0}$ (Control) & 1.09 & 0.80 & 0.76 & 1.08 & 0.93 \\
\hline $\mathrm{T}_{1}$ (Arjun) & 0.38 & 0.43 & 0.40 & 0.44 & 0.41 \\
\hline $\mathrm{T}_{2}$ (Kalam) & 0.76 & 0.57 & 0.74 & 0.88 & 0.74 \\
\hline Mean & 0.74 & 0.60 & 0.64 & 0.80 & \\
\hline Source & \multicolumn{2}{|c|}{ S. Em. \pm} & \multicolumn{2}{|c|}{ C.D. at $5 \%$} & C.V. \% \\
\hline $\mathrm{T}$ & \multicolumn{2}{|c|}{0.020} & \multicolumn{2}{|c|}{0.059} & \\
\hline $\mathrm{V}$ & \multicolumn{2}{|c|}{0.023} & \multicolumn{2}{|c|}{0.068} & 10.01 \\
\hline $\mathrm{T} \times \mathrm{V}$ & \multicolumn{2}{|c|}{0.040} & \multicolumn{2}{|c|}{0.118} & \\
\hline
\end{tabular}

intensity. The reduction in rate of evaporation due to low light condition might also resulted in more nitrogen supply to plants and thus increase the vegetative growth of crop. Moreover light availability is the most important factor for the performance of under storey crops, particularly where upper storey perennials form a dense canopy (Thakur and Singh, 2003; Thakur and Dutt, 2003). Maximum crop height was registered under eucalyptus reported by Gill (2001). Similarly higher plant height of turmeric was also reported by Gill et al. (2004) under poplar tree. Likewise, Kumar et al. (2010) also recorded higher plant height of safed musli under tamarind plantation as compared to open condition. Nayak et al. (2014) found that the height of pineapple under mangium recorded the maximum height $(82.7 \mathrm{~cm})$ while kalmegh under mangium recorded the minimum height $(32.8 \mathrm{~cm})$. The variation in height of different intercrops may be attributed to the genetically character of intercrops and availability of light intensity under trees. In case of second growth parameter, the maximum number of leaves (12.53) of green gram was recorded under control and minimum number of leaves (11.20) under Kalam (Table 2). Increase in number of leaves in present investigation might be due to increase in number of branches under study. The reason for more number of leaves under control at harvest stage might be due to more light availability and thus more photosynthesis. This increase in photosynthesis activity might have resulted in formation of more number of leaves in green gram. These results are in accordance with Mutanal et al. (2008) who reported significantly more number of leaves in agave under sole condition as compared to grown under tree. Nayak et al. (2014) reported that pineapple under open condition registered the maximum number of leaves (43.6) while mangoginger under mangium recorded the minimum of (6.9). In most of the crops the number of leaves (branches)/ plant was relatively higher in open condition than under tree canopy because of availability of more light. 
Similarly the maximum number of branches per plant (4.80) of green gram was recorded under control and minimum number of branches (2.96) in Arjun. The maximum number of branches (3.96) was recorded in $\mathrm{K}-851$ as compared to minimum (3.37) in GM-4 (Table 3).This may be due to more light availability in control (Open condition) and thus more photosynthesis. This increase in photosynthesis activity might have resulted in formation of more number of branches in green gram studied. Yield parameter like the maximum grain yield per plant (3.10 gm) of green gram was recorded under control as compared to minimum $(1.37 \mathrm{gm})$ in Arjun. The maximum grain yield per plant of $2.66 \mathrm{gm}$ was recorded in K-851as compared to minimum of $1.91 \mathrm{gm}$ in GM-4 (Table 4). The reason for more grain yield per plant under control may be due to green gram under open condition where there was less competition for synthesizing food materials and may also be due to more number of branches recorded in present study which might have increased the yield of green gram per plant. Significantly (at $\mathrm{P}=0.05$ ) higher grain yield was recorded by Thaware $e t$ al. (2004) in sole crop as compared to intercropping under trees in Maharashtra. Pandey and Tewari (2004) recorded higher grain yield in sole mung bean as compared to under tree. Another growth parameter the maximum grain yield per plot $(0.93 \mathrm{~kg})$ of green gram was recorded under treatment control as compared to minimum $(0.41 \mathrm{~kg})$ recorded under Arjun. The maximum yield per plot $(0.80 \mathrm{~kg})$ was recorded in treatment $\mathrm{K}-851$ as compared to minimum $(0.60 \mathrm{~kg})$ in $\mathrm{GM}-3$ (Table 5). The reason for more grain yield (kg) per plot under control may be due to green gram grown under open condition, where there was no competition of light by the crops for synthesizing food materials. More number of branches and grain yield per plant recorded in present study (Tables 3 and 4) were also contributing factors for the increased yield. These results are in accordance with those reported by Divya et al. (2006) who reported maximum increase in grain yield of french bean in sole cropping (Control). Mohsin (2005) recorded higher herbage and oil yield in all the Mentha spp. in pure crops condition than intercropped with poplar and eucalyptus. Similarly Mutanal et al. (2008) also reported highest fiber yield of agave in sole crop as compared to grown under tree. Average higher seed yield of mustard varieties per plot in open condition was also noted by Kumar et al. (2000) as compared to grown under neem tree. Misra (2014) found soybean growth and productivity varied considerably and it increased with a decrease in tree density of Gmelina arborea based agrisilvicultural system. Soybean yield varied between $1.5 \mathrm{Mg} \mathrm{ha}^{-1}$ to $2.1 \mathrm{Mg}$ $\mathrm{ha}^{-1}$. Nayak et al. (2014) also concluded that trend of crop yield under the trees and open condition was: Pineapple $>$ Aloevera $>$ Mangoginger $>$ Kalmegh when intercropped in Acacia mangium and Gmelina arborea based agrisilvicultural system. Similarly Newaj et al.
(2013) revealed that the grain yield of blackgram decreased with increasing growth of tree and yield reduction gone up to 14.3 to $23.8 \%$ at the end of rotation period of eucalyptus irrespective of spacing and clones. The yield reduction in agrisilviculture might be due to competition between eucalyptus and crop for light, moisture and nutrients. Like wise Mishra et al. (2004) have also reported about the decrease of soybean productivity under poplar clones in agrisilviculture system due to the competition for light and soil nutrients.

\section{Conclusion}

In the trial, K-851 variety showed superiority in growth as well as yield in number of leaves (12.31) and number of branches per plant (3.96) and grain yield (2.66 gm per plant and $0.80 \mathrm{~kg}$ per plot) among all the varieties tested under Arjun and Kalam based agrisilivicultural system. Therefore, this variety is suggested to grow in south Gujarat condition.

\section{REFERENCES}

Batish, D.R., Kohli, R.K., Jose, S. and Singh, H.P (2007). Ecological Basis of Agroforestry. CRC Press, New York.

CBD (2012). Biodiversity Complex, In: Commemoration of $11^{\text {th }}$ conference of parties (CoP -11) to CBD held during October 01-19, 2012 at Hyderabad, India. Pp. 230 (cited from https://www.cbd.int/cop/cop-11/doc/cop-11commemoration-en.pdf).

Chauhan, S.K., Dhillon, W.S., Singh, N. and Sharma, R. (2013). Physiological behaviour and yield evaluation of agronomic crops under agri-horti-silviculture system. International Journal of Plant Research, 3(1): 1-8.

Divya, M. P., Santhi, R. and Ramesh, K. R. (2006). Evaluation of suitable intercrops for Jatropha curcas based agroforestry systems. Indian Journal of Agroforestry, 8 (2): 1-4.

Dogra, A.S. (2007). Contribution of trees outside forests toward wood production and environmental amelioration. Indian Journal of Ecology, 38: 1-5.

Mohsin, F. (2005). Effect of litter fall of short-rotation tree on herbage and oil yield of aromatic plants under agroforestry system. Indian Journal of Agroforestry, 7(1): 25-31.

Gill, A.S. (2001) Effect of multipurpose tree species on the yield of wheat. Indian Journal of Agroforestry, 24(4): 484-489.

Gill, B.S., Singh, A., Singh, G. and Saini, S.S. (2001). Effect of age of poplar on growth and yield of turmeric (Curcuma longa L.) intercrop. Indian Journal of Agroforestry, 27(3): 313-315.

Kumar, R.D., Sreenivasulu, G.B., Prashanth, S.J., Jayaprakashnarayan, R.P., Nartraj, S.K. and Hegde, N.K. (2010). Performance of safed musli (Chlorophytum borivilianum L.) in tamarind plantation as intercrop and as sole crop in open area. International Journal of Agricultural Sciences, 6(1): 359-360.

Kumar, R.V., Gupta, V.K. and Ahlawat, S.P. (2000). Performance of mustard varieties under agroforestry system. Agroforestry in $21^{\text {st }}$ Century, Agrotech Publishing academy, Udaipur, pp.153-156. 
Mishra, A., Swamy, S.L. and Puri, S. (2004). Growth and productivity of soybean under five promising clones of Populus deltoides in agrisilviculture system. Indian Journal of Agroforestry, 6(2): 9-13.

Misra, A. (2014). Growth, biomass and crop productivity under different tree spacings of Gmelina arborea in agrisilviculture system. Paripex - Indian Journal of Research, 3(7): 228- 229.

Mutanal, S.M., Patil, S.J., Shahapurmath, G. and Maheswarappa, V. (2008). Growth and yield of agave under different tree species. Journal of Tropical forestry, 24 (2): 58-60.

Nayak, M.R., Behera, L.K., Mishra, P.J. and Bhola, N. (2014). Economics and yield performance of some short duration fruit and medicinal crops under agrisilvicultural system in rainfed uplands of Odisha. Indian Journal of Applied and Natural Science, 6 (1): 274-278.

Newaj, A., Handa, A.K. and Chaturvedi, O.P. (2013). Performance of intercrops with various clones of eucalyptus planted under agrisilviculture system. Indian Journal of Agroforestry, 15(1); 87- 90.

Pandey, A. and Tewari, S.K. (2004). Yield dynamics of mungbean (Vigna radiata L. Wilczek) varieties in Poplar Based Agroforestry System. Indian Journal of Agro-

$$
\text { forestry, 6(2): 89-91. }
$$

Pandey, D.N. (2007). Multifunctional agroforestry in India. Current Science, 92(4): 455-463.

Panse, V.G. and Sukhatme P.V. (1978). Statistical methods for agricultural workers. Indian Council of Agricultural Research, New Delhi.

Thakur, P.S. and Dutt, V. (2003). Performance of wheats as alley crop grown with Morus alba hedgerows under rainfed conditions. Indian Journal of Agroforestry, 1\&2: 36-44.

Thakur, P.S. and Singh, S. (2003). Influence of canopy size modification of Morus alba on productivity of Vigna mungo and Pisum sativum in agroforestry system. Indian Journal of Plant Physiology, Special issue: 104109.

Thaware, B.L., Bhagat, S.B., Khadtar, B.S. and Jadhav, B.B. (2004). Effect of tree species on growth and yield of rice (Oryza sativa L.) in Konkan region. Indian Journal of Agroforestry, 6(2): 15-18.

Thevathasan, N.V., Gordan, A.M., Simposon, J.A., Reynolds, P.E., Price, G.W. and Zhang, P. (2004). Biophysical and ecological interactions in a temperate treebased intercropping system. Journal of Crop Improvement, 12 (1-2): 339-363. 